\title{
Petrology and Geochemistry of Kimberlites from Liaoning and Shandong Provinces, China
}

\author{
Tompkins, L.A. ${ }^{1}$, Meyer, S.P. ${ }^{1}$, Han, Z. $^{2}$, and Hu, S. ${ }^{3}$
}

1. Astro Mining N.L., 46 Kings Park Rd, West Perth, 6005, Australia

2. $6^{\text {th }}$ Geological Brigade, Pulandian, Liaoning, China

3. $7^{\text {th }}$ Geological Brigade, Linyi, Shandong, China

Diamondiferous kimberlites of the Liaoning (Fuxian kimberlite province) and Shandong (Mengyin kimberlite province) Provinces (Fig. 1), China are located in the eastern portion of the Sino-Korean Craton (SKC), NE China. The SKC, one of three major Precambrian continental blocks in eastern China, is composed of two major Archaean continental nuclei that are surrounded by $\sim 1,800 \mathrm{Ma}$ orogenic belts. The plate tectonic history of the SKC is complex but it appears that it was attached to the Laurentia-Siberia supercontinent throughout most of the Proterozoic ( $\mathrm{Li}, 1997)$. During most of the Palaeozoic, the SKC drifted away from the supercontinent and remained as an isolated continent off East Gondwanaland. Suturing of the SKC to the Mongolian terranes in the north began in the Permian with the main suturing of the SKC with the southern continental terranes taking place from the Middle Triassic to Middle Jurassic (Li, 1997). By the mid-Cretaceous the SKC was firmly consolidated into its present position.

The eastern part of the SKC is cut by the Tan-Lu Fault (Fig. 1), a major tectonic zone that has a strike extent of over 4,000km extending NE into Far East Russia. Sinistral displacement of 520 to $740 \mathrm{~km}$ is documented along the southern portion of the Tan-Lu Fault, with movement taking place predominantly in the mid-Mesozoic. Precambrian movement on the Tan-Lu is debated, though it may have been at least a zone of crustal weakness in the Proterozoic. The Fuxian kimberlites, located east of the Tan-Lu Fault, are situated $\sim 500 \mathrm{~km}$ NE of the Mengyin kimberlites which were intruded west of the Tan-Lu Fault system. Radiometric dating on mineral separates from both the Mengyin and Fuxian province kimberlites yield an emplacement of age of $\sim 475 \mathrm{Ma}$ (Dobbs et al., 1991) for both provinces.

The Fuxian kimberlite province occurs in three, sub-parallel, ENE-trending belts within an area of $\sim 1,000 \mathrm{~km}^{2}$ near the large city of Wafangdian. There are over 110 known kimberlite dykes, small pipes, and/or blows along the dykes that intrude into Upper Proterozoic siltstones/sandstones, shales, and marls of the Nanfen Group or into Cambrian limestone. The largest known pipe (\#42, $4.2 \mathrm{ha})$ is subeconomic, and only one kimberlite, pipe 50 (0.64 ha), is presently being mined for diamonds at an average grade of $0.31-0.37 \mathrm{cpt}$ and at a rate of about 400,000 tonnes per annum. This pipe is located in the central kimberlite dyke trend. The absence of preserved crater facies kimberlite and the predominance of hypabyssal facies rocks, coupled with the abundance of dykes, and small pipes, indicate that the Fuxian province has undergone considerable erosion to expose the root zone facies.

Petrologically, the Fuxian kimberlites are composed of two generations of olivine pseudomorphed by serpentine and/or calcite, with groundmass phlogopite, fine-grained apatite and perovskite, all enclosed in a matrix of minor serpentine and abundant late-stage calcite. Opaque phases include well-developed atoll-textured spinels, xenocrystic chromite, and abundant secondary, fine-grained pyrite, galena and sphalerite. The sulfide phases are always in association with late-stage calcite in the groundmass, former-olivine crystals, and/or in cross-cutting veinlets. Overall, the Fuxian kimberlites are highly carbonated and chloritization of serpentine and phlogopite increases with the 
abundance of calcite. Unusual petrographic varieties of kimberlite with lamprophyric textures are documented in a number of dyke rocks (dykes 1,2,3). In particular, dyke 2 contains abundant former-olivine crystals with cores of $\mathrm{Cr}$-spinel, poikilitically enclosed within late-stage apatite crystals and long, tabular laths of second generation $\mathrm{Mg}$-phlogopite. First generation phlogopite is partially chloritized. Dyke 3 is extremely carbonated, but is associated spatially with 1 and 2 .

The Mengyin kimberlite Province consists of three kimberlite fields (Changma, Xiyu and Poli), with only the southernmost Changma field containing economic diamondiferous kimberlite. The kimberlites occur as NNE trending dikes, blows along the dikes and as small pipes. The only diamond mine is at pipe 701 ( $0.45 \mathrm{ha})$ where mining proceeds at an average grade of $1 \mathrm{cpt}$. Most of the kimberlites intrude Archaean granite (Changma field), but some, i.e. Poli and southern XiYu fields intrude Cambrian to Middle Ordovician limestone. Minerallogically the Mengyin kimberlites have been described as similar by Dobbs et al., 1991. They are composed of two generations of olivine pseudomorphed by serpentine ( + /- calcite), in a groundmass of phlogopite, monticellite, atoll-textured spinels, perovskite, apatite, serpentine and carbonate. Compared with the Fuxian kimberlites, the Changma kimberlites contain considerably less carbonate. As with the Fuxian province, the Mengyin fields are exposed root zone facies kimberlites.

Major element compositions of the Fuxian and Mengyin kimberlites are similar. The kimberlites are silica-undersaturated $\left(10-40 \mathrm{wt} \% \mathrm{SiO}_{2}\right)$ with the lower silica values $(<20 \mathrm{wt} \%)$ corresponding to highly carbonated samples (30 - $45 \mathrm{wt} \% \mathrm{CaO}$ ). They are rich in $\mathrm{MgO}$ (up to $33 \mathrm{wt} \% ; 28 \%$ dyke 2) and potassic to ultrapotassic with $\mathrm{K}_{2} \mathrm{O} / \mathrm{Na}_{2} \mathrm{O}$ ratios varying between 5-35 (average $=10-20 ; 35=$ dyke 2, Fuxian). Concentrations of $\mathrm{P}_{2} \mathrm{O}_{5}$ are up to $2.6 \mathrm{wt} \%$ (dyke 1, Fuxian), $\mathrm{Al}_{2} \mathrm{O}_{3}$ values are $<6$ $w t \%$ and $\mathrm{TiO}_{2}$ is up to $2.5 \mathrm{wt} \%$ (pipe 42 , Fuxian).

The kimberlites have high concentrations in the compatible trace elements with $\mathrm{Ni}$ up to 1,400 ppm and $\mathrm{Cr}$ up to 2,000 ppm. The rocks are enriched in the incompatible trace elements such as $\mathrm{Sr}$ (up to $1,800 \mathrm{ppm}$; pipe 50), Ba (up to $3,000 \mathrm{ppm} ; 8,000-9,000 \mathrm{ppm}$ for dykes 1 and 2), and LREE's (200 - 1,000 times chondrite abundances), and have steep REE patterns (La/Lu 50-100). High $\mathrm{P}_{2} \mathrm{O}_{5}$ and $\mathrm{Ce}$ (up to $600 \mathrm{ppm}$; dyke 3) concentrations correspond to the unusual apatite-rich dykes 1 and 2 , and dyke 3 . For the majority of the kimberlites, the moderately incompatible element $\mathrm{Nb}$ ranges from 10 to $200 \mathrm{ppm}$ and $\mathrm{Zr}$ from 100 to $300 \mathrm{ppm}$ with $\mathrm{Nb} / \mathrm{Zr}$ ratios $<1$. However, dykes 1,2 and 3 are distinctly enriched in $\mathrm{Nb}$ with values clustered around $350 \mathrm{ppm}$ and $\mathrm{Nb} / \mathrm{Zr}$ ratios of $\sim 1$.

Petrographically and geochemically the Fuxian and Mengyin kimberlites are most similar to the South African Group-I kimberlites. Differences are apparent by the higher modal abundances of apatite in the Fuxian kimberlites, a feature that is particularly evident in dykes 1 and 2. The latter are phlogopite-rich with $\mathrm{Ce}$ and $\mathrm{P}_{2} \mathrm{O}_{5}$ values similar to Group-II (phlogopite-rich) kimberlites, but their $\mathrm{Nb} / \mathrm{Zr}$ ratio are significantly higher than Group II kimberlites suggesting they are not derived from a lithospheric source. The timing of kimberlite emplacement is coincident with postulated large-scale plate motions of the large Gondwanaland continent to the west of the SKC (Li, 1997) and just prior to the onset of the Caledonian Orogeny and oceanic subduction along the margin of the SKC. Near-surface controls to pipe emplacement are considered to be splay faults off a larger Tan-Lu structure. At Fuxian, reaction of the intruding kimberlites with the surrounding limestone host-rock produced small-scale, post-emplacement, hydrothermal activity in the vicinity of the intrusions resulting in remobilisation of carbonate ( + sulfides) from the country rock into the kimberlites. The lamprophyric-textured dykes are highly incompatible-element enriched primary kimberlite melts that crystallized in a hypabyssal environment, and do not appear to be differentiate products of another kimberlite magma. 


\section{References}

Dobbs, P.N., Duncan, D.J., Hu, S, Shee, S.R., Colgan, E., Brown, M.A., Smith, C.B. and Allsopp, H.L., 1991, The geology of the Mengyin kimberlites, Shandong, China., In: O.H. Leonardos, H.O.A. Meyer, and J.C. Gaspar, editors, Kimberlites, Related Rocks and Mantle Xenoliths, Proceedings of the Fifth International Kimberlite Conference, Araxa, Brasil, CPRM Publication, Brasilia, vol. 1, 40-61.

Li, Z.X., 1997, Tectonic history of the major East Asian lithospheric blocks since the MidProterozoic - A synthesis., In: M.F.J. Flower et al., editors, Mantle Dynamics and Plate Interactions in East Asia, AGU Geodynamic Series, in press.

\section{Acknowledgements}

Permission to publish is granted by the Quantum-Astro Joint Ventures with the Chinese Geological Brigades of the Liaoning and Shandong Provinces.

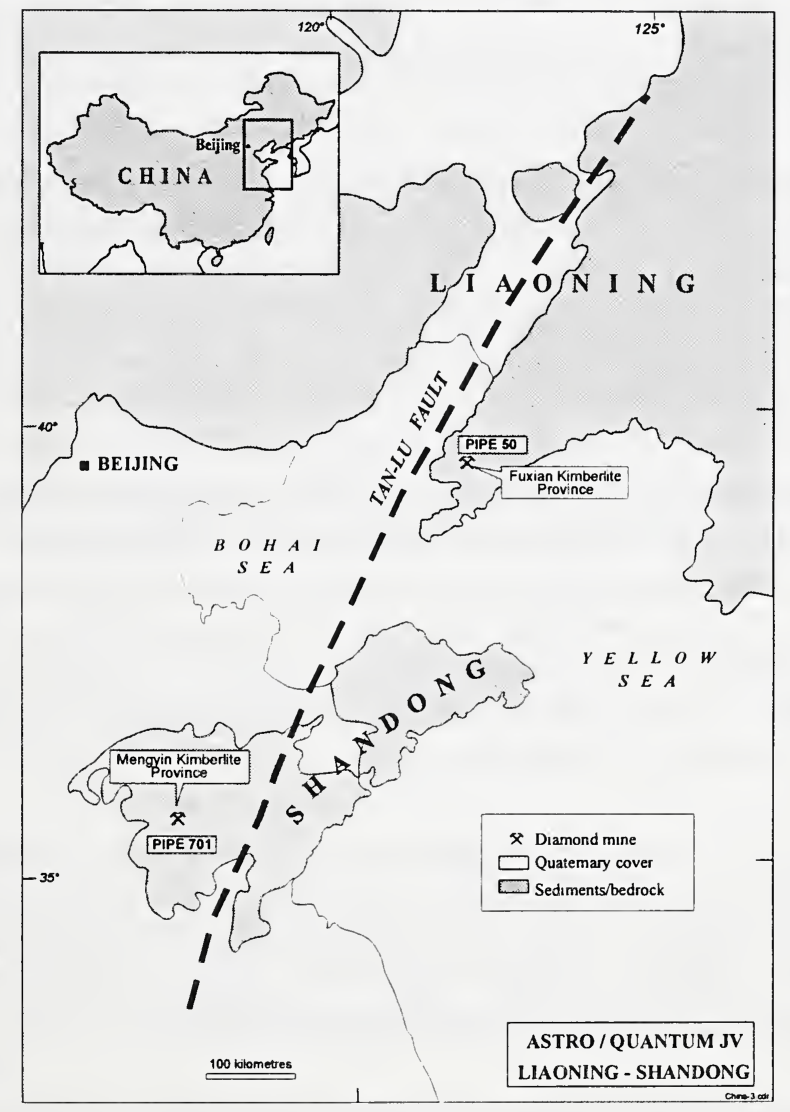

Figure 1. Location of the Mengyin and Fuxian Kimberlite Provinces, China. 